\title{
Tree Structural Diversity and Yield Prediction Models for Tree Species in Old Oyo National Park, Nigeria
}

\author{
Adesoji Akinwumi Adeyemi", Hussainat Taiwo Taofeek \\ Department of Forest Resources Management, Faculty of Agriculture, University of Ilorin, Ilorin, Nigeria \\ Email address: \\ adeyemi.aa@unilorin.edu.ng (A. A. Adeyemi), adeyemiadesoji@yahoo.com (A. A. Adeyemi) \\ ${ }^{*}$ Corresponding author
}

To cite this article:

Adesoji Akinwumi Adeyemi, Hussainat Taiwo Taofeek. Tree Structural Diversity and Yield Prediction Models for Tree Species in Old Oyo National Park, Nigeria. American Journal of Plant Biology. Vol. 5, No. 2, 2020, pp. 11-20. doi: 10.11648/j.ajpb.20200502.11

Received: April 14, 2020; Accepted: April 30, 2020; Published: June 9, 2020

\begin{abstract}
Evaluation of structural and species distribution is essential for conservation work. Besides, reliable baseline information is crucial for a sustainable forest management. We assessed forest structure and formulated yield-prediction models for tree species in Old Oyo National Park (OONP). Systematic sampling technique was adopted for the study. Thirty transects of $1000 \mathrm{~m}$-long were laid at $1 \mathrm{~km}$ intervals. Four 0.25 ha-plots were then alternately laid at $250 \mathrm{~m}$ intervals along each transect, and 120 plots were used for the study. Structural parameters including diameters at the base, breast height, middle, merchantable top and tree heights were measured for trees with $\mathrm{Dbh} \geq 10 \mathrm{~cm}$ to compute stand density and volume. Data were analysed using descriptive statistics and regression. Species diversity and richness indices were computed using ShannonWiener and Margalef's Indices. Models were assessed using $\mathrm{R}^{2}$ and standard error of estimate (SEE), overall significance of each model was evaluated using F-test. Model validation was done using t-test and bias. Sixty-four tree species in 23 families were encountered with richness and diversity indices of 1.189 and 3.544, respectively. Only one endangered (Pterocarpus erinaceus) and three vulnerable (Afzelia africana, Vitellaria paradoxa and Maranthes agnesis) species were encountered. Burkea africana was the most locally-abundant in the area with a relative density and basal area of 9.3 and $3.058 \mathrm{~m}^{2} / \mathrm{ha}$, respectively. Fabaceae was the most-represented family. The best yield-prediction model was of the form: $V=27.53+$ $21.41 \log D B+0.023 T H T^{2}$ having $\mathrm{R}^{2}$, SEE and bias values of $90.5 \%, 0.599$ and 0.005 , respectively. It is recommended for future predictions.
\end{abstract}

Keywords: Structural Diversity, Species Composition, Richness, Yield Prediction

\section{Introduction}

Forests form an integral part of life on earth, providing a range of benefits at local, national and global levels, covering approximately $30.6 \%$ of the world's total land mass [1]. Tropical forested areas in Nigeria support high levels of biodiversity, but human interferences have played a destructive role in natural forest existence [2]. The conservation of plant diversity has received considerably less attention than the conservation of animals, perhaps because plants lack the popular appeal of many animal groups [3]. As a result, plant conservation is greatly under-resourced in comparison with fauna conservation [4]. Yet, plants are much more important. Animals can provide proteins, leather, fur and other products, but none of these are necessities for human survival and well-being, and would not survive without reasonable collections of trees [5].

Forests provide a large collection of ecosystem functions and services. They produce wood for pulp and timber, and contribute to the regulation of the carbon and water cycles [6]. Besides, they host a major part of the world's biodiversity, and provide numerous cultural services and possibilities for recreation activities [6, 7]. Several decades of biodiversity research in grasslands suggest that plant diversity is a key driver of ecosystem functioning; it enhances primary productivity and increases resistance against herbivores [6].

Despite the immense benefits of forest and trees, they have disappeared at an alarming rate due to socio-economic changes such as infrastructural transformation, increasing commercialization of agricultural production, and high rate of urbanization, which result in large-scale destruction of the 
natural forests. It is difficult to regenerate the existing forests and establishing new plantations by individuals, private bodies and government due to lack of proper knowledge about most species, and their silvicultural requirements [8]. High species diversity is considered as a desirable state, and that the knowledge of species diversity is particularly useful when one wishes to study the influence of biotic disturbances, or to know the state of succession and stability in the ecosystem $[9,10]$. The diversity of life forms may be directly correlated to tree species diversity, or inversely correlated as in transitional forest-types characterized by diversity patterns at different geographic scales. Within the National Parks of Nigeria are some of the very few remaining natural ecosystems in the country, capable of enhancing ecological processes and life support system [11]. These parks are part of the efforts of the governments of Nigeria at conserving forests.

The environmental significance of the parks is mainly to establish an ecologically and geographically balanced network of protected areas under the control and jurisdiction of the Federal Government. They are expected to play a pivotal role in the conservation of biological diversities in the country [12]. In furtherance of these objectives, her management is to advise the Federal Government on the development and preservation including the financial requirements for the implementation of such policies. According to Reddy and Ugle [13], sustainable management techniques are required to maintain the biodiversity and productivity of tropical forest ecosystems, and this can only be possible through genuine information about the status and distribution of tree species, which form the frame for other life forms. Many of the once diverse natural forests have been lost to the plantation of exotic species and agricultural practices [7]. Consequently, there are severe ecological and environmental changes, reducing the stabilizing functions of the forest. Although, biodiversity is conventionally measured in terms of genetics, species and ecosystem diversity [14, 15], Nigeria's rich biodiversity is highly influenced by its enormous anthropogenic forces and the floral diversity has however been poorly documented.

Although there are many univariate techniques for data analysis in statistics, none of them takes into account the effects of other variables [16]. In such a case regression models are being used. Generally, measuring breast height diameter is simpler, more accurate, less time consuming and cheaper than measuring tree height. Consequently, in forest inventories, diameter is measured for all the sampled trees, but height is measured only for a subsample of trees. From these measurements, statistical models are fitted to define the relation between these two variables [17, 18]. The most common procedure is to use an established height-diameter model to predict tree heights from field measurements of tree diameters $[19,20]$.

Modelling is a method of developing equation using linear prediction function, and unknown regression equation parameters are estimated from the data [21]. Regression analyses are used for data description (descriptive factors), prediction, parameters estimation and control [22].
Regression analysis is mainly used to predict variable values by the values of one or more independent variables [23]. Tree slenderness coefficient (TSC) has been used as the simplest empirical stability indicator for single tree or stand dimensions [24]. It is the ratio of tree total height to diameter at breast height (Dbh), with both variables measured in the same unit [25]. According to Wang et al. [26], the susceptibility of a stand to wind-induced damage is largely influenced by the TSC. The size of trees, their shape and structure influence mechanical stability [27]. Therefore, in order to predict the stability and susceptibility of a stand to damage, accurate information about TSC of a stand becomes very essential. Furthermore, tree crown condition is a good indicator of the health of a tree as it plays a key role in tree primary productivity provides habitats for myriads of wildlife [8].

Literature is replete with different tree growth models, which predict yields of forests and in recent time, the study on TSC is becoming significant in quantitative forestry following the susceptibility of many exotic species to natural phenomenon such as wind damage, breaking or uprooting of live tree as a result of high intensity of wind components [24]. Sustainable forest and forest resources management requires reliable estimates of growing stock. This is because such information guides forest managers in timber evaluation as well as in the allocation of forest areas for harvest [18, 28]. For timber production as well as other purposes, an estimate of growing stock is often expressed in terms of volume, which can be estimated from easily measurable tree dimensions such as diameter at breast height and tree height. The roles of models in tree volume estimation especially in tropical natural forest ecosystem cannot be overestimated [29]. Models are veritable tools for effective management of any forest stand. Models in forestry are tools for providing long-term decision-making, estimation of growing stock, timber valuation and allocation of forest areas for harvest. According to Avery and Burkhart [30], volume equations can be used to estimate the average content of standing trees of various sizes and species. Akindele and LeMay [31] reported that growing stock in forestry is usually expressed in terms of timber volume and the most common procedure of obtaining this is the use of allometric equations based on relationship between volume and variables such as diameter and height. The main reason for conducting forest inventory either in the plantations or natural forest ecosystem is to estimate timber volume of the plots installed in the entire stand.

Nigeria's rich biodiversity is highly influenced by enormous anthropogenic forces and the floral diversity has however been poorly-documented, especially in most of the gazetted areas with a particular reference to Old Oyo National Park. Up till now, information on status of the trees in the park appears to be non-existent. For a sound forest management option, baseline data are crucial. The knowledge of species composition in the park remains inadequate despite the recognition of the immense relevance of trees. Structural information, which forms essential components of any sustainable forest management planning are yet unavailable. Little is known about the tree diversity of the 
park. Hitherto, no tree growth prediction models have been developed for sustainable management of the forest in the park. The ever-increasing demands for forest goods and services has brought about intense pressure on the forest ecosystem and forest products, thereby leading to rapid disappearance of forest and loss of important species in natural habitats [7]. As a result of this pressure, many once-diverse natural ecosystems have been lost to plantation of exotic species and agricultural practices. Thus, it is important to have information about the natural forest as this may facilitate the formulation of sustainable forest management strategies and effective conservation work.

\section{Methodology}

\subsection{Study Area}

Old Oyo National Park (OONP) is located across northern Oyo State and southern Kwara State. The park is 251,200 ha of land on latitudes $8^{\circ} 15^{\prime}$ and $9^{\circ} 00^{\prime} \mathrm{N}$, and longitude $3^{\circ} 35^{\prime}$ and $4^{\circ} 42^{\prime} \mathrm{E}$ (Figure 1). The location has inevitably placed the park at a vantage position of abundance land area as well as diverse wildlife and cultural/historical settings. Vegetation of the area has been classified as southern guinea savannah. There are three watersheds in Old Oyo National Park: River Ogun and its numerous tributaries, River Tessi and its tributaries and River Iwa and its tributaries. Annual rainfall in the park ranges between $900 \mathrm{~mm}$ and 1,500 mm, and mean annual temperature is between 12 and $37^{\circ} \mathrm{C}$. The rainy season begins in April through September with peak between July and August. Temperature is highest in the dry season with the mean daily maximum, which is greatest during February and March with about $33.6^{\circ} \mathrm{C}$ with the lowest values of about $20^{\circ} \mathrm{C}$ during the peak of harmattan in December and January.

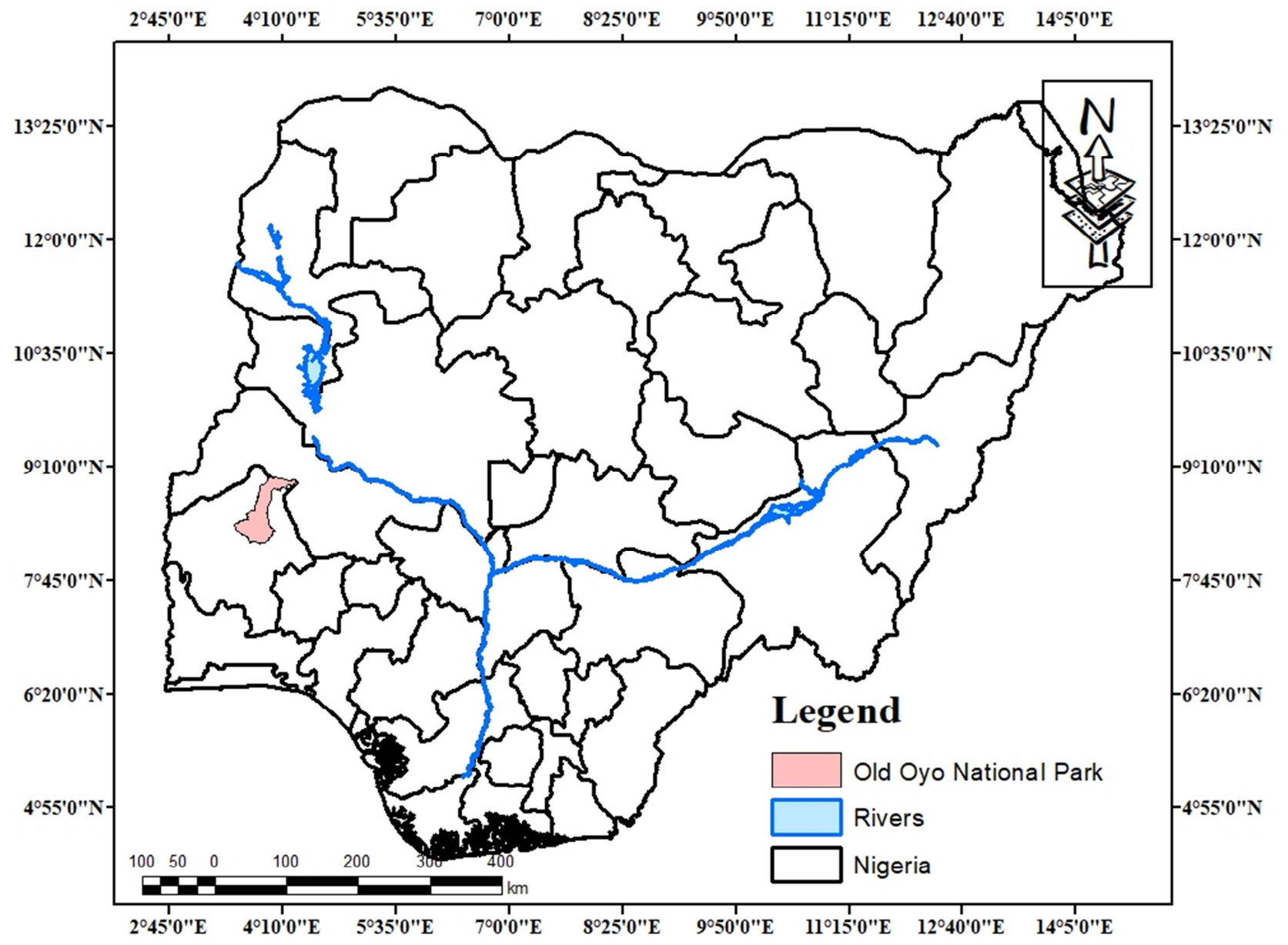

Figure 1. Map of the study area

\subsection{Sampling Procedure and Data Collection}

Systematic line transect technique was adopted for sample plot location. Thirty transects of $1000 \mathrm{~m}$ long, evenly distributed over the five (5) camps of the OONP were laid at $1 \mathrm{~km}$ intervals. Four plots of $50 \mathrm{~m} \times 50 \mathrm{~m}(0.25 \mathrm{ha})$ were then laid alternately at $250 \mathrm{~m}$ intervals along each transects (Figure 2). A total of 120 sample plots (30 ha) were used for the study. The service of an experienced taxonomist was employed for tree species identification. In the study area, all living trees with $\mathrm{Dbh} \geq 10 \mathrm{~cm}$ were identified by species, and measured. Tree growth parameters were measured using diameter tape, and Spiegel relaskop for measuring heights, diameter at the top and middle of the trees. All other important species below $10 \mathrm{~cm}$ in Dbh were recorded. All the 
identified species were defined based on their IUCN status using IUCN Red List of Threatened species [32].

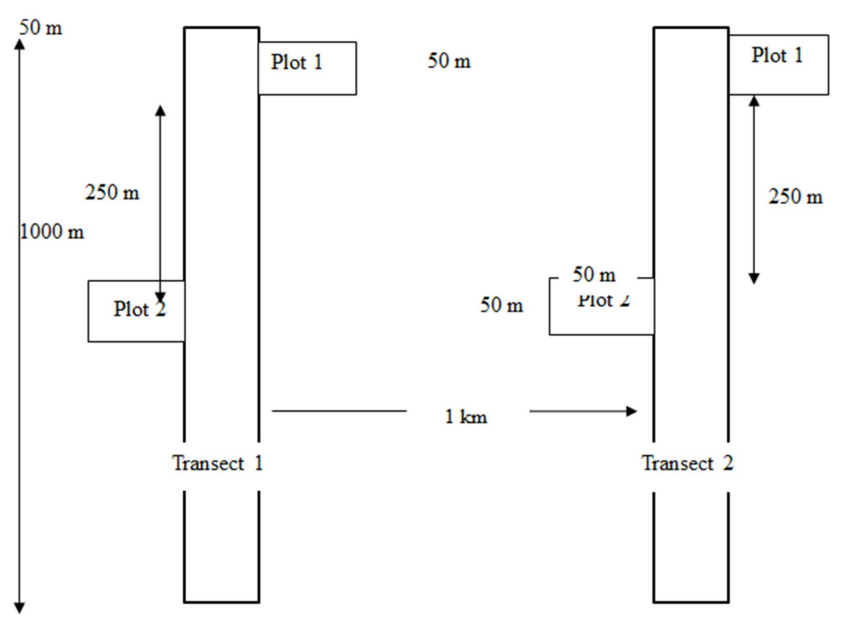

Figure 2. Sample plots' layout using systematic sampling technique.

\subsection{Data Analysis}

The data on tree species were analyzed using, relative density, Shannon-Wiener diversity index, species richness, stand density and slenderness coefficient. Relative density $(\mathrm{RD})$ for each of the tree species was determined using:

$$
R D(\%)=\left(\frac{n_{i}}{N}\right) \times 100
$$

Where; $n i=$ number of individual species, $\mathrm{N}=$ total number of species in the sampled area.

Tree species diversity was computed using ShannonWiener Diversity Index as:

$$
H^{\prime}=-\sum_{t=1}^{S} P_{i} \ln \left(P_{i}\right)
$$

Where; $S=$ total number of species in the community, $P_{i}=$ proportion of $\mathrm{S}$ made up of the $i$ th species, $l n=$ natural logarithm.

Tree species richness was computed using Margalef's index as:

$$
d=\frac{s}{\sqrt{N}}
$$

Where; $\mathrm{S}=$ the number of species encountered, $\mathrm{N}=$ the total number of individuals of all the tree species.

Basal area

Individual tree basal areas were computed using:

$$
B A=\frac{\pi \mathrm{Dbh}^{2}}{4}
$$

Where; Dbh=diameter at breast height (m).

Slenderness coefficient

Tree slenderness coefficient (SC) for all measured trees was computed using:

$$
S C=\frac{\text { Total height }}{\text { Dbh }}
$$

Volume estimation

Individual tree volumes were computed using Newton's formula [33]:

$$
V=\frac{h}{24}\left(D_{b}+4 D_{m}+D_{t}\right.
$$

Where; $D_{b}, D_{m}, D_{t}=$ tree diameters at the base, middle and top of merchantable height in $\mathrm{cm}$, respectively, $\mathrm{h}=$ tree merchantable height $(\mathrm{m})$. The plot volume was obtained by adding the volumes of all the trees in the plot, and the perhectare volumes were obtained by multiplying the plot volumes by 4 .

Descriptive statistics

Descriptive statistics such as mean and graphs were used to summarize the tree growth parameters and stand density.

\subsection{Modelling}

The following model functions were tried:

$$
\begin{aligned}
& \mathrm{V}=\mathrm{b}_{\mathrm{o}}+\mathrm{b}_{1} \mathrm{SC}+\mathrm{b}_{2} \mathrm{SQ}^{2}+\mathrm{b}_{3} \log \mathrm{Dbh} \\
& \mathrm{V}=\mathrm{b}_{\mathrm{o}}+\mathrm{b}_{1} \mathrm{SQ}^{2}+\mathrm{b}_{2} \mathrm{SC}^{2}+\mathrm{b}_{3} \mathrm{Dbh} \\
& \mathrm{V}=\mathrm{b}_{\mathrm{o}}+\mathrm{b}_{1} \log \mathrm{SQ}+\mathrm{b}_{2} \log \mathrm{BA}+\mathrm{b}_{3} \mathrm{SC} \\
& \mathrm{V}=\mathrm{b}_{\mathrm{o}}+\mathrm{b}_{1} \log \mathrm{SQ}^{2}+\mathrm{b}_{2} \mathrm{SC}+\mathrm{b}_{3} \mathrm{BA} \\
& \mathrm{V}=\mathrm{b}_{\mathrm{o}}+\mathrm{b}_{1} \log \mathrm{BA}+\mathrm{b}_{2} \operatorname{logSC}+\mathrm{b}_{3} \mathrm{MHT}^{2}
\end{aligned}
$$

Where; $\mathrm{SQ}=$ stem quality, MHT=merchantable height, $b_{o}, b_{l}$, $b_{2}$ and $b_{3}=$ regression parameters to be estimated. Models were adopted from Adeyemi and Ugo-Mbonu [24], and modified for this study.

\subsection{Models Assessment}

\section{F-test}

This was used to test the overall significance of the models. The critical values of $F$ (i.e., F-tabulated) at $\alpha=0.05$, were compared with the variance-ratio. Where the variance ratio (F- calculated) is greater than the critical values (F-tabulated), such equation is significant, and can therefore be accepted for volume prediction in the study area.

Coefficient of Determination $\left(R^{2}\right)$

This is a measure of the proportion of variation in the dependent variable that is being explained by the behaviour of the independent variable. For the model to be accepted, the $R^{2}$ must be high (at least, $\geq 50 \%$ ).

$$
R^{2}=1-\frac{S S E}{S S T}
$$

Where; SSE=error sum of squares, $\mathrm{SST}=$ total sum of squares.

\section{Standard Error Estimate (SEE)}

$$
\mathrm{SEE}=\sqrt{\frac{\sum_{i=1}^{n}\left(V_{\text {obs. }}-V_{\text {pred. }}\right)}{n-k}}
$$

Where; $\quad V_{\text {obs }}=$ observed (computed) volume value, $V_{\text {pred. }}=$ predicted volume values, $\mathrm{k}=$ number of parameters in the fitted model, $n=$ number of trees in the model-fitting dataset. 


\subsection{Models Validation}

For model validation, data were divided into two sets (i.e. model-formulating set and model-validating set). The modelformulating set was used for developing the models and the usefulness of the models were validated using the modelvalidating set. The following statistics were then computed:

The student $t$-test

This was used to test for significant differences between the actual volume values and the model outputs (predicted values) of the various models developed.

Bias

This was used to examine the absolute differences between the computed volumes and the model outputs, as:

$$
\text { Bias }=\sum \frac{V_{2}-V_{1}}{V_{2}}
$$

Where; $\mathrm{V}_{2}=$ actual (observed) volume, $\mathrm{V}_{1}=$ predicted volume from the models.

\section{Results}

A total of 64 tree species, belonging to 23 families were identified in the area. Burkea africana was the most frequently-occurring species in the area, having RD of $9.3 \%$
(Table 1). The least-occurring species were Lecaniodiscus cupanioides, Ficus thonningii, Lannea schimperi, Maranthes agnesis, Myrianthus arboreus, Securidaca longipedunculata, Securinega virosa, Sterculia setigera, Strychnos spinosa and Vitex doniana with less than one tree/ha. The species richness index for the area was 1.189 and the diversity index was 3.544. Burkea africana has the highest basal area/ha of 3.058 $\mathrm{m}^{2} / \mathrm{ha}$, followed by Vitellaria paradoxa with $2.367 \mathrm{~m}^{2} / \mathrm{ha}$. The least-occurring species in the area were Lecaniodiscus cupanioides $\left(0.010 \mathrm{~m}^{2} / \mathrm{ha}\right)$, Ficus thonningii $\left(0.048 \mathrm{~m}^{2} / \mathrm{ha}\right)$, Lannea schimperi $\left(0.005 \mathrm{~m}^{2} / \mathrm{ha}\right)$, Maranthes agnesis $(0.035$ $\left.\mathrm{m}^{2} / \mathrm{ha}\right)$ and Vitex doniana $\left(0.028 \mathrm{~m}^{2} / \mathrm{ha}\right)$. The Fabaceae was observed to be the most prevalent family $(26.6 \%)$. Most of the species encountered have not been assessed against the IUCN-standard. Only one (Pterocarpus erinaceus) of the species is endangered according to the IUCN Red List. There were three vulnerable species (i.e. Afzelia africana, Maranthes agnesis and Vitellaria paradoxa) present in the area. Five tree species (Azadirachta indica, Detarium microcarpum, Isoberlinia doka, Nauclea latifolia and Vitex doniana) classified as Least Concern were also encountered in the area. Table 2 presents individual tree and stand structural variables in the five ranges of the study area.

Table 1. Tree species composition and their IUCN status in OONP.

\begin{tabular}{|c|c|c|c|c|c|}
\hline Species & Family & N/ha & BA/ha $\left(\mathrm{m}^{2}\right)$ & RD\% & IUCN Status \\
\hline Acacia polycantha & Fabaceae & 6 & 0.012 & 1.5 & Not assessed \\
\hline Acacia seyal & Fabaceae & 4 & 0.021 & 0.9 & Not assessed \\
\hline Afzelia africana & Fabaceae & 2 & 0.077 & 0.5 & Vulnerable \\
\hline Annona senegalensis & Annonaceae & 27 & 0.037 & 7.2 & Not assessed \\
\hline Anogeissus leiocarpa & Combretaceae & 26 & 2.348 & 6.9 & Not assessed \\
\hline Azadirachta indica & Meliaceae & 2 & 0.368 & 0.4 & Least concern \\
\hline Azanza garkeana & Malvaceae & 2 & 0.072 & 0.5 & Not assessed \\
\hline Bridelia ferruginea & Euphorbiaceae & 4 & 0.284 & 1.1 & Not assessed \\
\hline Burkea africana & Fabaceae & 35 & 3.058 & 9.3 & Not assessed \\
\hline Combretum molle & Combretaceae & 5 & 0.525 & 1.2 & Not assessed \\
\hline Combretum nigricans & Combretaceae & 4 & 0.259 & 1.1 & Not assessed \\
\hline Crossopteryx febrifuga & Rubiaceae & 5 & 0.371 & 1.2 & Not assessed \\
\hline Cussonia arborea & Araliaceae & 4 & 0.165 & 1.0 & Not assessed \\
\hline Cussonia bateri & Araliaceae & 4 & 0.407 & 1.0 & Not assessed \\
\hline Detarium microcarpum & Fabaceae & 15 & 1.806 & 3.9 & Least concern \\
\hline Detarium senegalense & Fabaceae & 2 & 0.083 & 0.5 & Not assessed \\
\hline Distemonanthus benthamianus & Fabaceae & 2 & 0.101 & 0.4 & Not assessed \\
\hline Entada africana & Fabaceae & 2 & 0.125 & 0.5 & Not assessed \\
\hline Ficus sp. & Moraceae & 5 & 0.192 & 1.1 & Not assessed \\
\hline Ficus thonningii & Moraceae & 1 & 0.048 & 0.2 & Not assessed \\
\hline Gardenia aqualla & Rubiaceae & 9 & 0.019 & 2.4 & Not assessed \\
\hline Gardenia sokotensis & Rubiaceae & 7 & 0.008 & 1.8 & Not assessed \\
\hline Grewia mollis & Malvaceae & 10 & 0.032 & 2.5 & Not assessed \\
\hline Hymenocardia acida & Phyllanthaceae & 15 & 1.509 & 4.0 & Not assessed \\
\hline Isoberlinia doka & Fabaceae & 7 & 0.588 & 1.7 & Least concern \\
\hline Lecaniodiscus cupanioides & Sapindaceae & 0.04 & 0.010 & 0.04 & Not assessed \\
\hline Lannea acida & Anacardiaceae & 3 & 0.205 & 0.7 & Not assessed \\
\hline Lannea schimperi & Anacardiaceae & 0.04 & 0.005 & 0.04 & Not assessed \\
\hline Lophira lanceolata & Ochnaceae & 8 & 0.649 & 2.1 & Not assessed \\
\hline Maytenus senegalensis & Celastraceae & 5 & 0.211 & 1.2 & Not assessed \\
\hline Monotes kerstingii & Dipterocarpaceae & 7 & 0.576 & 1.8 & Not assessed \\
\hline
\end{tabular}




\begin{tabular}{|c|c|c|c|c|c|}
\hline Species & Family & N/ha & BA/ha $\left(\mathrm{m}^{2}\right)$ & RD\% & IUCN Status \\
\hline Myrianthus arboreus & Urticaceae & 1 & 0.719 & 0.2 & Not assessed \\
\hline Nauclea latifolia & Rubiaceae & 5 & 0.282 & 1.3 & Least concern \\
\hline Parinari maranthes & Chrysobalanaceae & 5 & 0.285 & 1.3 & Not assessed \\
\hline Parinari polyandra & Chrysobalanaceae & 5 & 0.367 & 1.1 & Not assessed \\
\hline Parkia biglobosa & Fabaceae & 3 & 0.117 & 0.8 & Not assessed \\
\hline Pericopsis laxiflora & Fabaceae & 2 & 1.693 & 0.6 & Not assessed \\
\hline Piliostigma thonningii & Fabaceae & 22 & 0.553 & 5.9 & Not assessed \\
\hline Prosopis africana & Fabaceae & 7 & 1.186 & 1.9 & Not assessed \\
\hline Pseudocedrela kotschyi & Meliaceae & 10 & 0.841 & 2.6 & Not assessed \\
\hline Pterocarpus erinaceus & Fabaceae & 7 & 0.023 & 1.7 & Endangered \\
\hline Securidaca longipedunculata & Polygalaceae & 1 & 0.074 & 0.2 & Not assessed \\
\hline Securinega virosa & Euphorbiaceae & 1 & 0.041 & 0.3 & Not assessed \\
\hline Sterculia setigera & Sterculiaceae & 1 & 0.141 & 0.1 & Not assessed \\
\hline Stereospermum kunthianum & Bignoniaceae & 3 & 0.142 & 0.7 & Not assessed \\
\hline Strychnos innocua & Loganiaceae & 3 & 0.036 & 0.8 & Not assessed \\
\hline Terminalia glaucescens & Combretaceae & 11 & 1.962 & 3.0 & Not assessed \\
\hline Terminalia microptera & Combretaceae & 17 & 0.207 & 4.5 & Not assessed \\
\hline Trichilia emetic & Meliaceae & 5 & 0.243 & 1.1 & Not assessed \\
\hline Uapaca togoensis & Phyllanthaceae & 3 & 2.637 & 0.8 & Not assessed \\
\hline Vitellaria paradoxa & Sapotaceae & 25 & 0.028 & 6.6 & Vulnerable \\
\hline Vitex doniana & Verbenaceae & 1 & 0.074 & 0.1 & Least concern \\
\hline Total & & 378 & 28.89 & 100 & \\
\hline
\end{tabular}

$\mathrm{N}$ - number of trees; BA - basal area.

Table 2. Descriptive statistics for individual tree and stand growth variables.

\begin{tabular}{|c|c|c|c|c|c|}
\hline Range & Growth variable & Mean & SD & Min & Max \\
\hline \multirow[t]{6}{*}{ Marguba } & MHT (m) & 7.98 & 2.18 & 4.0 & 16.8 \\
\hline & $\operatorname{Dbh}(\mathrm{cm})$ & 21.80 & 5.54 & 11.78 & 61.12 \\
\hline & $\mathrm{BA} / \mathrm{ha}\left(\mathrm{m}^{2}\right)$ & 0.265 & 0.017 & 0.007 & 0.196 \\
\hline & $\mathrm{SC}(\mathrm{m})$ & 38.01 & 11.88 & 13.53 & 91.79 \\
\hline & $\mathrm{V} / \mathrm{ha}\left(\mathrm{m}^{3}\right)$ & 2.83 & 1.87 & 1.00 & 23.00 \\
\hline & $\mathrm{N} / \mathrm{ha}$ & 359 & & & \\
\hline \multirow[t]{6}{*}{ Tede } & MHT (m) & 8.86 & 3.74 & 2.30 & 23.00 \\
\hline & $\operatorname{Dbh}(\mathrm{cm})$ & 18.39 & 6.39 & 9.20 & 50.29 \\
\hline & $\mathrm{BA} / \mathrm{ha}\left(\mathrm{m}^{2}\right)$ & 0.198 & 0.015 & 0.004 & 0.132 \\
\hline & $\mathrm{SC}(\mathrm{m})$ & 54.48 & 29.43 & 9.84 & 164.17 \\
\hline & $\mathrm{V} / \mathrm{ha}\left(\mathrm{m}^{3}\right)$ & 2.75 & 1.31 & 0.60 & 10.02 \\
\hline & $\mathrm{N} / \mathrm{ha}$ & 365 & & & \\
\hline \multirow[t]{6}{*}{ Sepeteri } & MHT (m) & 7.63 & 1.86 & 4.00 & 15.00 \\
\hline & $\operatorname{Dbh}(\mathrm{cm})$ & 13.18 & 3.60 & 6.53 & 25.46 \\
\hline & $\mathrm{BA} / \mathrm{ha}\left(\mathrm{m}^{2}\right)$ & 0.010 & 0.006 & 0.002 & 0.034 \\
\hline & $\mathrm{SC}(\mathrm{m})$ & 61.14 & 19.84 & 20.82 & 152.01 \\
\hline & $\mathrm{V} / \mathrm{ha}\left(\mathrm{m}^{3}\right)$ & 2.20 & 0.83 & 1.04 & 5.86 \\
\hline & $\mathrm{N} / \mathrm{ha}$ & 346 & & & \\
\hline \multirow[t]{6}{*}{ Oyo-Ile } & MHT (m) & 8.31 & 1.88 & 2.90 & 13.25 \\
\hline & Dbh $(\mathrm{cm})$ & 14.98 & 4.69 & 9.55 & 32.47 \\
\hline & $\mathrm{BA} / \mathrm{ha}\left(\mathrm{m}^{2}\right)$ & 0.013 & 0.009 & 0.005 & 0.055 \\
\hline & $\mathrm{SC}(\mathrm{m})$ & 60.04 & 20.44 & 11.09 & 131.31 \\
\hline & $\mathrm{V} / \mathrm{ha}\left(\mathrm{m}^{3}\right)$ & 2.68 & 1.00 & 0.66 & 7.17 \\
\hline & $\mathrm{N} / \mathrm{ha}$ & 423 & & & \\
\hline \multirow[t]{6}{*}{ Yemeso } & MHT (m) & 7.62 & 1.64 & 4.00 & 13.00 \\
\hline & Dbh (cm) & 16.09 & 5.07 & 9.55 & 40.74 \\
\hline & $\mathrm{BA} / \mathrm{ha}\left(\mathrm{m}^{2}\right)$ & 0.013 & 0.011 & 0.005 & 0.087 \\
\hline & $\mathrm{SC}(\mathrm{m})$ & 54.92 & 18.68 & 16.94 & 126.83 \\
\hline & $\mathrm{V} / \mathrm{ha}\left(\mathrm{m}^{3}\right)$ & 2.54 & 1.05 & 1.07 & 7.79 \\
\hline & N/ha & 249 & & & \\
\hline
\end{tabular}

MHT - tree merchantable height, V - tree merchantable volume.

The result of slenderness coefficient (SC) categorization for trees in the study area revealed that about 177 trees/ha had low slenderness coefficient (i.e. SC $<70$ ), constituting $76.2 \%$ of the trees encountered per hectare. This implies high stability, and low susceptibility to wind-induced damages or breakages. There were 30 trees/ha (13.1\%) with moderate slenderness coefficient (i.e. SC: 70-80). Trees with high slenderness coefficient $(\mathrm{SC}>80)$ were $25 /$ ha $(10.7 \%)$, implying that very few of the trees/ha might be susceptible to wind-throw (Figure 3).

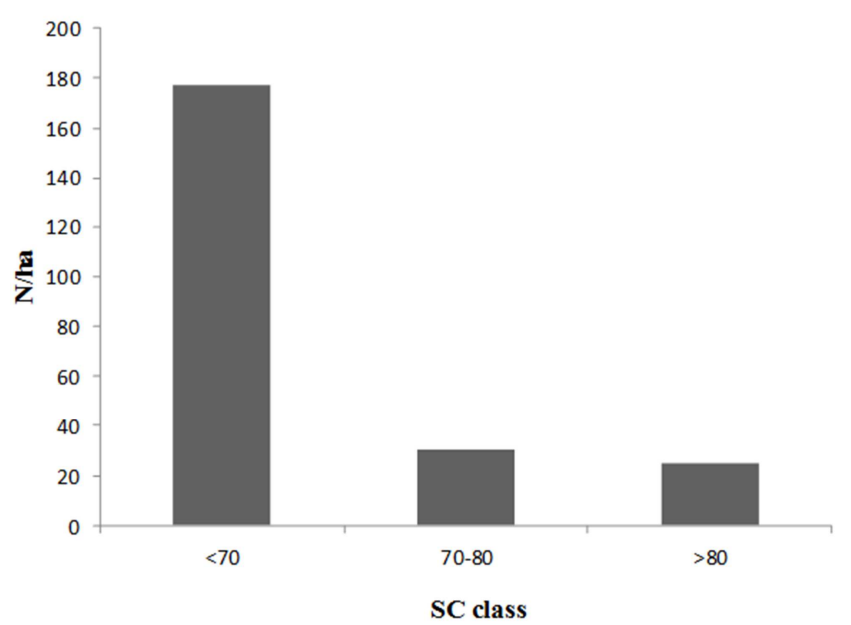

Figure 3. SC classes for tree species in the study area.

Parameter estimates of the models for predicting tree stem volume of species encountered in the study area are presented in Table 3. The intercepts (a) were far from 1 under models $2,3,5$ and 6 while the slope $\left(b_{1}\right)$ were close to zero under models 1, 2, 3, 4, 6 and 7. Model 5 had the farthest value of slope from zero (8.765). 
Table 3. Parameter estimates of the models.

\begin{tabular}{|c|c|c|c|c|c|}
\hline \multirow{2}{*}{$\mathbf{S N}$} & \multirow{2}{*}{ Models } & \multicolumn{4}{|c|}{ Parameter estimate } \\
\hline & & $\mathbf{a}$ & $\mathbf{b}_{1}$ & $\mathbf{b}_{2}$ & $\mathbf{b}_{3}$ \\
\hline 1 & $\mathrm{~V}=\mathrm{a}+\mathrm{b}_{1} \mathrm{SC}+\mathrm{b}_{2} \mathrm{SQ}^{2}+\mathrm{b}_{3} \log \mathrm{Dbh}$ & -5.382 & 0.184 & 0.374 & 1.114 \\
\hline 2 & $\mathrm{~V}=\mathrm{a}+\mathrm{b}_{1} \mathrm{SQ}^{2}+\mathrm{b}_{2} \mathrm{SC}^{2}+\mathrm{b}_{3} \mathrm{Dbh}$ & -2.297 & 0.036 & 0.003 & 0.094 \\
\hline 3 & $\mathrm{~V}=\mathrm{a}+\mathrm{b}_{1} \log \mathrm{SQ}+\mathrm{b}_{2} \log \mathrm{BA}+\mathrm{b}_{3} \mathrm{SC}$ & 5.807 & 0.250 & 7.607 & 0.200 \\
\hline 4 & $\mathrm{~V}=\mathrm{a}+\mathrm{b}_{1} \log \mathrm{SQ}^{2}+\mathrm{b}_{2} \mathrm{SC}+\mathrm{b}_{3} \mathrm{BA}$ & -1.007 & 0.349 & 0.136 & 9.615 \\
\hline 5 & $\mathrm{~V}=\mathrm{a}+\mathrm{b}_{1} \log \mathrm{BA}+\mathrm{b}_{2} \log \mathrm{SC}+\mathrm{b}_{3} \mathrm{MHT}$ & -1.312 & 8.765 & 9.688 & -0.027 \\
\hline 6 & $\mathrm{~V}=\mathrm{a}+\mathrm{b}_{1} \log \mathrm{DB}+\mathrm{b}_{2} \mathrm{THT}^{2}+\mathrm{b}_{3} \mathrm{DB}$ & 27.529 & -21.408 & 0.023 & 0.194 \\
\hline
\end{tabular}

The model assessment results for species in the study area are presented in Table 4. All the models were good for prediction going by their $\mathrm{R}^{2}$-values (at least, $>50 \%$ ) and significance of the models $(\mathrm{P}<0.05)$. All models except model 6 had SEE values of $>1$ (Table 4$)$. The best model was model 6 with $\mathrm{R}^{2}$-value and SEE value of $90.5 \%$ and 0.599 , respectively. This was followed by model 4 with $\mathrm{R}^{2}$ and SEE values of $72.6 \%$ and 1.015 , respectively. The least-suitable model was model 2 with $\mathrm{R}^{2}$ and SEE values of $64.2 \%$ and 1.163 , respectively.

Table 4. Model assessment results.

\begin{tabular}{|c|c|c|c|c|c|}
\hline SN & Model & $\mathbf{F}$ & $\mathbf{P}$ & $\mathbf{R}^{2}$ & SEE \\
\hline 1 & $\mathrm{~V}=-5.382+0.184 \mathrm{SC}+0.374 \mathrm{SQ}^{2}+1.114 \log \mathrm{Dbh}$ & 1541.264 & 0.000 & 72.7 & 1.014 \\
\hline 2 & $\mathrm{~V}=-2.297+0.036 \mathrm{SQ}^{2}+0.003 \mathrm{SC}^{2}+0.094 \mathrm{Dbh}$ & 1037.865 & 0.000 & 64.2 & 1.163 \\
\hline 3 & $\mathrm{~V}=5.805+0.250 \log \mathrm{SQ}+7.607 \log \mathrm{BA}+0.200 \mathrm{SC}$ & 1076.738 & 0.000 & 65.0 & 1.148 \\
\hline 5 & $\mathrm{~V}=-1.312+8.765 \log \mathrm{BA}+9.688 \operatorname{logSC}+-0.027 \mathrm{MHT}$ & 1338.745 & 0.000 & 69.8 & 1.066 \\
\hline 6 & $\mathrm{~V}=27.529+-21.408 \log \mathrm{DB}+0.023 \mathrm{THT}^{2}+0.194 \mathrm{DB}$ & 5506.149 & 0.000 & 90.5 & 0.599 \\
\hline 7 & $\mathrm{~V}=2.645+-0.006 \mathrm{SQ}^{2}+0.501 \mathrm{THT}+3.862 \operatorname{logBA}$ & 1404.505 & 0.000 & 70.8 & 1.049 \\
\hline
\end{tabular}

The results of model validation are presented in Table 5. The result revealed that most of the developed models differed insignificantly in mean observed and predicted stem volumes. Models 1, 2 and 5 are not good models going by their significance in the observed and predicted volumes.
However, models 3, 4, 6 and 7 were good for prediction since the predicted volume values were not significantly different from the measured (observed) values $(\mathrm{P}>0.05)$. The bias values of the four models were also very small (Table 5).

Table 5. Model validation results.

\begin{tabular}{|c|c|c|c|c|}
\hline SN & Models & t-test & p-value & Bias \\
\hline 1 & $\mathrm{~V}=-5.382+0.184 \mathrm{SC}+0.374 \mathrm{SQ}^{2}+1.114 \log \mathrm{Dbh}$ & 59.344 & 0.000 & 0.8423 \\
\hline 2 & $\mathrm{~V}=-2.297+0.036 \mathrm{SQ}^{2}+0.003 \mathrm{SC}^{2}+0.094 \mathrm{Dbh}$ & 48.981 & 0.000 & 0.8204 \\
\hline 3 & $\mathrm{~V}=5.805+0.250 \operatorname{logSQ}+7.607 \log \mathrm{BA}+0.200 \mathrm{SC}$ & 0.075 & 0.940 & 0.0013 \\
\hline 4 & $\mathrm{~V}=-1.007+0.349 \operatorname{logSQ} \mathrm{S}^{2}+0.136 \mathrm{SC}+9.615 \mathrm{BA}$ & 0.032 & 0.974 & 0.0006 \\
\hline 5 & $\mathrm{~V}=-1.312+8.765 \log \mathrm{BA}+9.688 \log \mathrm{SC}+-0.027 \mathrm{MHT}$ & 5.665 & 0.000 & -0.0618 \\
\hline 6 & $\mathrm{~V}=27.529+-21.408 \log \mathrm{DB}+0.023 \mathrm{THT}^{2}+0.194 \mathrm{DB}$ & 0.419 & 0.675 & 0.0050 \\
\hline
\end{tabular}

\section{Discussion}

Tree species of about 64 in 23 families are lower compared to the 125 species belonging to 36 families reported by Adeyemi et al. [7] for Okwangwo Forest in northern Cross River State and 102 tree species belonging to 35 families reported by Edet et al. [34] for Afi Mountain Wildlife Sanctuary, which have some similarities with the study area. However, the species encountered were more than 10 tree species in 8 families recorded by Ibe et al. [35] in Ohaji/Egbema Watershed in Imo State. Vulnerable tree species that were identified based on IUCN categories in the course of this study include Afzelia africana, Maranthes agnesis and Vitellaria paradoxa. While Isoberlina doka, Azadirachta indica, Detarium microcarpum, Nauclea latifolia and Vitex doniana are Least Concern. Pterocarpus erinaceus is endangered, and the other tree species were not yet assessed [32]. The reason for the poor establishments of some families in the area may be attributed to anthropogenic activities prevalent in the study area, which might have prevented successful regenerations due to over-exploitation of some mother trees. It is also possible that most of the seeds or other propagules needed for growth enhancement were harvested for human consumption, and this might hinder propagation of those species. This is in line with Wardle et al. [36] observations, that anthropogenic activities have great deleterious consequences on the abundance of tree species.

The overall mean basal area per hectare recorded in this study was higher than the values of $11.39 \mathrm{~m}^{2}$ reported by Akinsanmi and Akintunde [37] and $1.1091 \mathrm{~m}^{2}$ reported by 
Ibe et al. [35], implying better structural diversity. The higher basal area may be due to the presence of adapted root architecture to absorb nutrients for growth. This corroborates the work of Parthasarathy [38], who noted that the adaptation of particular species to an environment may enhance their growth and establishment. However, this negates the influence that human use-pressure might have on any ecosystem, especially in developing world, where up to $70 \%$ of the population leave in rural areas, and are heavily dependent on forest resources, especially non-timber forest resources. The study area is characterized by abundance of trees with small Dbh. This is similar to the finding of Jimoh et al. [39]. The possibilities are that most trees in the large diameter classes were constantly exploited, often times, illegally. This also gives an impression of the structure proposed for a natural forest by Husch et al. [33].

All the measured trees in the area had low slenderness coefficient, which implies high stability, and low susceptibility to wind-induced damage or breakage. Trees with high slenderness coefficient are more susceptible to breakage than those with low slenderness coefficients [24, 40]. The best volume prediction model is of the form: $V=27.529+-21.408 \log D B+0.023 T H T^{2}+0.194 D B$. This model had properties, which hitherto, had not been used or considered. Diameter at the base (DB) was rarely seen in use for modeling, but its efficacy in approximating stem volume prediction is really noteworthy. It is a parameter, which is very easy to measure with inexpensive instruments. The standard error of estimate is a good measure of overall predictive value of regression equations $[9,18,31]$, and the value was really very small, just as the bias values, particularly for this predictionsuitable model. Generally, in this study, standard error of estimate (SEE) ranged between 0.599 and 1.163. Models with high index of fit such as $\mathrm{R}^{2}$ are indicators of a suitable model with good fit [20, 24, 29].

\section{Conclusion}

This study has shown that OONP has moderately-high species diversity. However, use-pressure impacted negatively on the local species abundance. Although it appeared that conservation efforts in the study area are worthwhile, much needed to be done to ensure that over-exploitations of valuable trees species are halted. Families noted with dominant species in the area are Fabaceae and Combretaceae. However, most tree species encountered in the area are not yet assessed against IUCN-standard, and only very few species can be said to be abundant in the area due to use-pressure. The overall mean Dbh $(16.76 \mathrm{~cm})$ in the area was lesser than the national minimum $(48 \mathrm{~cm})$ as stipulated by logging policy of Nigeria. This means, there should not be exploitation in the area in the first place. Although most of the trees measured had low to medium slenderness coefficients, which implies that most of the trees were of good vigour and could withstand wind-throw, this may have resulted from the fact that tall trees were already selectively logged, and illegally, since the area is under protection by law. Hence, responsible agency should be more sensitivelyintolerant to all forms of logging in the area. The park management should mostly concentrate on blocking known leakages, and make all culprits to face full wrath of the law, otherwise the area might soon be a history. There should be frequent tree species monitoring involving biodiversity and structural assessments for possible changes, either positive or otherwise. Tree growth parameters, especially tree diameter at the base and height proved to be good predictors of tree volume. The best model developed was of the form: $V=27.529+-21.408 \log D B+0.023 T H T^{2}+0.194 D B$ with $\mathrm{R}^{2}$, SEE and bias values of $90.5 \%, 0.599$ and $0.0050 \%$, respectively. It is therefore recommended for predictions in the study area.

\section{Acknowledgements}

The authors are truly grateful to the National Park Service for granting permissions on two occasions to conduct non-destructive biological surveys within its estate. The staff of the Old Oyo National Park are sincerely appreciated for their supports and understanding in the course of fieldworks.

\section{References}

[1] FAO (2018): The State of the World's Forests 2018 - Forest Pathways to Sustainable Development. Rome.

[2] Boboye, O. and Jimoh S. O. (2016). Pattern of Plant Species Diversity in a Dry Forest Ecosystem of Nigeria. Journal of Forestry Research and Management 13: 31-47.

[3] Goettsch, B., Hilton-Taylor, C., and Cruzpinon, G. (2015). High Proportion of Cactus Species Threatened with Extinction. Nation Plants 1: 15142.

[4] Havens, K., Kramer, A. T. and Guerrant, E. O. (2014). Getting Plant Conservation Right (Or Not): the Case of the United States. International journal of Plant Science 175 (3): 10.

[5] Corlett, R. T. and Primack, R. B. (2011). Tropical Rain Forests: an Ecological and Bio-geographical Comparison. 2nd edition. Wiley-Blackwell, Oxford, UK. ISBN: 978-1-44433255-1.336pp.

[6] Haase, J., Castagneyrol, B., Cornelissen, J. H. C., Ghazoul, J., Kattge, J., Koricheva, J., Scherer-Lorenzen, M., Morath, S. and Jactel, H. (2015). Contrasting Effects of Tree Diversity on Young Tree Growth and Resistance to Insect Herbivores Across Three Biodiversity Experiments. Oikos 10 (1111): 02090.

[7] Adeyemi, A. A., Ibe, A. E. and Okedinma, F. C. (2015). Tree Structural and Species Diversities in Okwangwo Forest. Cross River State, Nigeria. Journal of Research in Forestry, Wildlife and Environment 7: 36-53.

[8] Adeyemi, A. A., Jimoh, S. O. and Adesoye, P. O. (2013). Assessment of Tree Diversities in Oban Division of the Cross River National Park (CRNP). Nigeria Journal of Agriculture, Forestry and Social Sciences 11 (1): 216-230. 
[9] Adeyemi, A. A. (2012). Allometric Equations for Three Members of Olacaceae (R. Br.) Family in a Tropical Rainforest of Nigeria. Journal of Agriculture, Forestry and the Social Sciences 10 (2): 156-167.

[10] Moses, F. and Anthony, K. (2015). Assessment of Trees Species Diversity in Taia Riverine Forest along Njala Community, Moyamba district, Sierra Leone. Journal of Sustainable Environmental Management 7: 11-20.

[11] National Park Service (2010). www.nigeriaparkservice.org.

[12] Mohammed, S. O., Gajere, E. N., Eguaroje, E. O., Shaba, H., Ogbole, J. O., Mangut, Y. S., Onyeuwaoma, N. D. and Kolawole, I. S. (2013). Spatio-Temporal Analysis of the National Parks in Nigeria Using Geographic Information System. Ife Journal of Science 15 (1): 159.

[13] Reddy, S. C. and Ugle, P. (2008). Tree Species Diversity and Distribution Patterns in Tropical Forest of Eastern Ghats, India: A case study. Journal of Life Science 5 (4): 87-93.

[14] FAO (2010): Global Forest Resources Assessment (2005 and 2010) and the State of the World's Forests. Food and Agricultural Organization of the United Nations. Rome, Italy.

[15] Bello, A. G., Isah, A. D. and Ahmad, B. (2013). Tree Species Diversity Analysis of Kogo Forest Reserve in North-Western, Nigeria. International Journal of Plant, Animal and Environmental Sciences 3 (3): 189-196.

[16] Kahyani, S., Hosseini, S. M. and Basiri, R. (2011). The Basic of Analytical of Simple Linear Regression in Forestry Studies (Case Study: Relationship between Basal Area and Tree Coverage of Quercus brantii Lindl. In Absardeh, Chahar Mahale and Bakhtiari). World Applied Sciences Journal 14 (10): 1599-1606.

[17] Young, J. L., Dean W. C., Jung, K. P., Sung, H. K., Woo, K. L. and Jung, K. C. (2009). A Mixed Effects Height- Diameter Model for Pinus densiflora Trees in Gangwon Province, Korea. Journal of Korean Forest Society 98 (2): 178-17.

[18] Adeyemi, A. A. and Adesoye, P. O. (2010). Site Quality Assessment and Yield Models for Tectona grandis (Linn. F.) Stands in Ibadan Metropolis. Nigerian Journal of Forestry 40 (2): 67-77.

[19] Matthias, S., Andres, K. and Klaus, V. G. (2010). A Spatially Explicit Height-Diameter Model for Scots Pine in Estonia. European Journal of Forest Resources 130 (2): 1-3.

[20] Adeyemi, A. A. and Ukaegbu, O. C. (2016). Tree Heightdiameter and Yield Functions for Gmelina arborea (ROXB.) Stand in Edondon Gmelina Plantation, Cross River State, Nigeria. Journal of Research in Forestry, Wildlife and Environment 8 (2): 14-28.

[21] Shuaibu, R. B. and Alao, J. S. (2016). Multiple Linear Regression Tree Stem Volume Equations for the Estimation of Merchantable Volume of Azadirachta Indica (Neem Tree) in North-West Region of Nigeria. International Journal of Forestry and Horticulture 2 (1): 1-10.

[22] Montgomery, D. C., Peck, E. A. and Vining, G. G. (2001). Introduction to Linear Regression Analysis. $3^{\text {rd }}$ Edition, Wiley, New York.

[23] Reimann, C., Filzmoser P., Garrett R. G. and Dutter R. (2008). Statistical Data Analysis Explained. John Wiley \& Sons.
[24] Adeyemi, A. A. and Ngo-Mbonu, N. A. (2017). Tree Slenderness Coefficients and Crown Ratio Models for Gmelina arborea (Roxb) Stand in Afi River Forest Reserve, Cross River State, Nigeria. Nigerian Journal of Agriculture, Food and Environment 13 (1): 226-233.

[25] Nunes, L., Tome, J. and Tome, M. (2010). Stability of Pure Even-aged Conifer Stands in Portugal. In IUFRO Conference, Mixed and Pure Forests in a Changing World-Vila Real: UTAD. 3pp.

[26] Wang, Y., Titus S. J., and Lemay V. M. (1998). Relationship between Tree Slenderness Coefficients and Tree or Stand Characteristics for Major species in Boreal Mixed Forest. Canadian Journal of Forest Resources 28: 1171-1183.

[27] James, K., Haritos, N. and Ades, P. (2006). Mechanical Stability of Trees under Dynamic Loads. American Journal of Botany 93 (10): 1522-1530.

[28] Adesoye, P. O. (2014). Canopy Layers Stratified Volume Equations for Pinus caribaea Stands in South West Nigeria using Linear Mixed Models. South-east European Forestry 5 (2): $153-161$.

[29] Adekunle, V. A. J. (2007). Non-Linear Regression Models for Timber Volume Estimation in Natural Forest Ecosystem, Southwest Nigeria. Research Journal of Forestry 1: 40-54.

[30] Avery, T. E. and Burkhart, H. (2011). Forest Measurements, 5th edition. McGraw-Hill, NewYork.

[31] Akindele, S. O. and LeMay, V. M. (2006). Development of Tree Volume Equations for Common Timber Species in the Tropical Rain Forest Area of Nigeria. Forest Ecology and Management 226: 41-48.

[32] IUCN (2019). The IUCN Red List of Threatened Species. Version 2019 1. <www.iucnredlist.org>.

[33] Husch, B., Beers, T. W. and Kershaw, J. A. Jr. (2003). Forest Mensuration. 4th Edition, John Wiley and Sons Inc., New Jersey, USA. 949pp.

[34] Edet, D. I., Ijeomah, H. M. and Ogogo, A. U. (2011). Preliminary Assessment of Tree Species Diversity in Afi Mountain Wildlife Sanctuary, Southern Nigeria. Agriculture and Biology Journal of North America 3 (12): 486-492.

[35] Ibe, A. E., Onuoha, G. N., Adeyemi, A. A., Ogueri, C. U., Ibe M. A. and Okafor D. C. (2014). Assessment of Ecological Status and Tree Diversity in Ohaji/Egbema Watershed, SouthEastern, Nigeria. International Journal of Natural and Applied Sciences 10 (1): 21-33.

[36] Wardle, D. A., Walker, L. R. and Bardgett, R. D. (2004). Ecosystem Properties and Forest Decline in Contrasting LongTerm Chronosequence. Science 305: 509-513.

[37] Akinsanmi, F. A. and Akintunde, S. P. (2016). Analysis of Carbon Sequestration Potential of Tree Species in Agba Forest Reserve, Ilorin, Kwara State. Proceedings of the $38^{\text {th }}$ Annual Conference of the Forestry Association of Nigeria (FAN). Mangroves and Wetland of Sub-Saharan Africa: Potential for Sustainable Livelihood and Development. Pp. 653-662.

[38] Parthasarathy, N. (1999). Tree Diversity and Distribution in Undisturbed and Human Impacted Sites of Tropical Wet Evergreen Forest in Southern Western Ghats. India Biodiversity Conservation 8: 1365-1381. 
[39] Jimoh, S. O., Adesoye, P. O., Adeyemi, A. A. and Ikyaagba, E. T. (2012). Forest Structure Analysis in the Oban Division of Cross River National Park, Nigeria. Journal of Agricultural Science and Technology B2: 510-518.
[40] Adeyemi. A. A. and Adesoye, P. O. (2016). Evaluation of Some Weibull Parameter Estimation Methods for Characterizing Stem Diameter Distribution in a Tropical Mixed Forest of Southern Nigeria. Journal of Statistical Science and application 4 (11-12): 257-275. 